\title{
FILOZOFIJA ODGOJA I ODGOJNA ULOGA PRIČANJA PRIČA O KRŠENJU LJUDSKIH PRAVA
}

\author{
Milena Radovan Burja \\ Odjel za izobrazbu učitelja i odgojitelja, \\ Sveučilište u Zadru, Hrvatska \\ milena.radovan@unizd.hr
}

Primljeno: 17. 11. 2017.

\begin{abstract}
Učlanku se ukazuje na mogućnost da se pomoću filozofskog promišljanja odgojne uloge pričanja priča prepoznaju $i$ analiziraju pitanja $i$ problemi vezani uz razne oblike nepoštivanja, zloupotreba $i$ kršenja ljudskih prava. Pričanje priča kao odgojna aktivnost može biti usmjereno dodatnom osvještavanju pojava koje ugrožavaju moral $i$ vladavinu prava u društvu. Priče - koje mogu poslužiti kao jedan od važnih izvora za razumijevanje konteksta unutar kojega se odvijaju zamišljena ili stvarna životna suočavanja s problemima takve prirode - treba kritički i suosjećajno promišljati kako bi se aktivirala osobna i društvena odgovornost u vezi poštivanja ljudskih prava.
\end{abstract}

Ključne riječi: filozofija odgoja, priče, ljudska prava, odgoj, kritičko promišljanje, odgovornost

\section{Uvod u filozofsko promišljanje odgojne uloge pričanja priča}

Pričanje priča koristi se kao sredstvo za posredovanje poruka o događajima i ljudima, njihovim sudbinama, težnjama i iskustvima, bez obzira na medij i bez obzira jesu li sadržaji koje priča posreduje izmišljeni ili istiniti. Kako priča posreduje između sadržaja i onoga koji sagledava taj sadržaj, ona je prilika za otvaranje svojevrsnog dijaloga i rasprave o pitanjima i problemima koje kazuje priča, kao i prilika za traganje za rješenjima, što je ujedno i filozofski pristup.

Pričanje priča već se dugo koristi u odgoju, a posebno priča s moralnim značenjem, s ciljem ostvarenja neke moralne namjere i potica- 
nja poželjnog ponašanja. Današnja usmjerenost na odgojnu ulogu priča je slojevitija te zahvaća svu složenost odgojnih i životnih situacija koje uključuju moralne, kulturne, pravne i političke sklopove unutar kojih se raspravlja o različitim pojavama vezanima uz suvremeni život i s njima povezanim odgojnim izazovima. Posebno se priče danas koriste kao podrška i kao sredstvo za odgoj kritičkoga mišljenja, što je među ostalima uvelike promovirao M. Lipman kroz program filozofije za djecu od 1960-ih godina. Pričanje priča je i dalje jedan od važnih načina pomaganja djetetova razvoja i odgoja budućeg građanina u demokratskom društvu. Za djecu, posebno mlađu, priča je dio stvarnosti na koji se oni mogu osloniti, priče odgovaraju na neke njihove potrebe i pomažu im da se orijentiraju u okruženju u kojemu se odvija njihov razvoj. Priča ih motivira na dijalog s drugima, otvara ih za mišljenja koja slobodno konfrontiraju s drugačijim mišljenjima te ih navodi na tolerantnije razumijevanje i prihvaćanje stavova i vrijednosti drugih. Djeca također mogu razvijati empatiju ako ih se pomoću priča stavlja u situacije uživljavanja u osjećaje i doživljaje drugih ljudi. Dijelovi priče i dijelovi stvarnosti tako se zajedno slažu da bi se bolje razumjela stvarnost i problemi koji se javljaju u životu, odnosno da bi ih se otvoreno i odgovorno propitivalo.

U smislu doprinosa demokratskom odgoju građana, Martha C. Nussbaum kroz zagovaranje uloge književne imaginacije prepoznaje vrijednost priča za poticanje filozofske rasprave o stvarnim ili zamišljenim problemima s kojima se ljudi susreću, a što je iskustvo koje se može i odgojno koristiti. Alasdair MacIntyre iz svoga razumijevanja narativnog objašnjava kako slušanje priča omogućuje djeci postupno učenje o tome kako svijet stvarno funkcionira. Pritom naglašava povijesnost, jer

»... čovjek je u svom djelovanju i praksi, baš kao i u svojim izmišljenim pričama, bitno pripovjedačka životinja. On to nije u svojoj biti, nego postaje kroz svoju povijest, pripovjedač pričâ što pretendiraju na istinitost.« (MacIntyre, 2002, 233)

Objašnjavajući da je dio čovjekova razumijevanja pojedinačnih težnji i djelovanja sadržan u odgovoru na pitanje o tome kojih smo priča dio, MacIntyre nastavlja:

»... u ljudsko društvo stupamo s jednim ili više pripisanih karaktera - ulogâ koje su nam dodijeljene - i mi ih moramo naučiti da bismo mogli razumjeti kako drugi reagiraju na nas i kako naše reakcije na njih mogu biti protumačene. Upravo kroz slušanje priča o zlim maćehama, izgubljenoj djeci, dobrim 
ali zavedenim kraljevima, vučicama koje doje svoje blizance, najmlađim sinovima koji ostaju bez nasljedstva pa moraju uspjeti u životu i najstarijim sinovima što rasipaju svoje nasljedstvo na razuzdan život pa odlaze u progonstvo živjeti među svinjama, djeca uče, ili pak krivo uče, što je dijete, a što roditelj, koji su mogući likovi u drami u koju su rođenjem dospjeli, te kako svijet općenito funkcionira.« (MacIntyre, 2002, 233)

Iz tog razloga MacIntyre smatra važnim da svako društvo omogući svojim članovima načine razumijevanja društva, naravi ljudskoga djelovanja i stvaranja identiteta kako bi održalo i razvijalo uljuđenost i odgovarajuće funkcioniralo. Smatram da je odgoj u tome važna sastavnica. Filozofija odgoja također se sve više uključuje u rasprave o odgojnoj ulozi priča, na široj razini sagledavajući odgoj kao egzistencijalnu i vrijednosnu kategoriju te kao način čovjekova povijesna opstanka, promišljanja sredstava i postupaka odgojnoga djelovanja i perspektiva. Unutar toga ovdje se posebno osvrćem na odgojnu ulogu priča u prepoznavanju pitanja i problema vezanih uz nepravde, manipulacije, zloupotrebe i razna nepoštivanja prava u svakodnevnom životu, jer bi i to trebao biti sadržaj koji može obogatiti sva područja kurikuluma kroz poučavanje i filozofske rasprave, pomažući čovjeku da se potpunije razvija u ljudskom i moralnom smislu.

Martha C. Nussbaum u tome smislu i književnu imaginaciju smatra »bitnim sastojkom etičkoga stajališta koje od nas traži da se brinemo za dobrobit drugih ljudi, čiji su životi drugačiji od naših" (Nussbaum, $2005,16)$. Briga za druge podrazumijeva osjetljivost na ono što se događa drugima i u društvu. Posebno se to odnosi na iskustvo nepravdi odnosno kada zakazuje uvažavanje čovjeka i njegovih prava ne samo u smislu da se ne suzbija njihovo kršenje nego često sama država ne čini dovoljno za osiguravanje pretpostavki koje su nužne za vladavinu prava. Kroz odgoj i obrazovanje treba otvarati put znanju i svijesti o važnosti poštivanja ljudskih prava, njegovati kritičko ali i suosjećajno razumijevanje svijeta, tako da svaki pojedinac osjeća da se »među njegovim najvažnijim moralnim sposobnostima nalazi ta da je u stanju živo zamisliti što znači biti svaka od tih osoba čiju situaciju zamišlja« (Nussbaum, 2005, 104).

\section{Uloga priča sa sadržajima o ljudskim pravima}

U današnjem globaliziranom svijetu suočavamo se s raspravama o različitim pitanjima koja smo na široj društvenoj razini možda osvijes- 
tili, ali ih još uvijek nedovoljno uključujemo u odgoj. Tim više možemo teme moralnosti, ljudskih prava i kršenja ljudskih prava odgojno raspraviti pomoću priča. Ljudska se prava još uvijek svakodnevno krše diljem svijeta te, iako su ti problemi vidljiviji i dostupniji svakom čovjeku posredstvom sredstava suvremene komunikacije, oni se ne rješavaju brzo. S jedne strane, ljudi su svjesniji problema i potrebe za angažiranjem, dok smo s druge strane također svjesniji sve veće nemoći našeg utjecaja na stvarno rješavanje izazovnih pitanja. Uzroci se mogu pronaći u različitoj postavljenosti odnosa moći u pojedinom društvu i u različitim dijelovima svijeta, u stupnju razvijenosti, razini obrazovanosti te u nejednakim stvarnim mogućnostima sudjelovanja građana u odlučivanju o pojedinim temama.

Nussbaum je toga svjesna te podcrtava ulogu pričanja priča u poticanju književne imaginacije. Navodi da se time pomaže razvoj sposobnosti povezanih s modelom humanoga razvoja u demokratskom društvu. Razvoj sposobnosti Nussbaum (2003) smatra nužnim kada se govori o šansama za realiziranje svake osobe u kontekstu stvarnog korištenja prava. Ukazuje kako uskraćivanje mogućnosti pojedincu na razvoj vlastitih sposobnosti proizvodi razna kršenja ljudskih prava u raznim dijelovima svijeta. Amartya Sen (2007) također ističe važnost razvoja ljudskih sposobnosti u smislu potrebe omogućavanja transformacije svakog ljudskog resursa u sposobnosti, što utječe na mogućnost većeg sudjelovanja osobe u ekonomskom prosperitetu i razvoju samoga sebe i društva. Sen također upozorava na teška kršenja ljudskih prava kroz nepravednu distribuciju resursa - siromaštvu doprinosi propuštanje razvijanja temeljnih sposobnosti jer se ne pruža mogućnost adekvatnog obrazovanja i ne pruža se šansa za korištenje svih svojih sposobnosti za poboljšanje života. To vodi strukturalnom kršenju ljudskih prava jer institucije moći direktno odlučuju o distribuciji resursa. Negiranje jednog prava povlači i uvećava negiranje ostalih prava te ljudi koji imaju manje moći i kojima su resursi nedostupniji ostaju više ili manje trajno izloženi trpljenju povrede njihovih prava.

Iako se pomoću raznih međunarodnih i nacionalnih dokumenata deklarativno jamči poštivanje prava - od građanskih i političkih, preko socijalnih i ekonomskih, do prava na budućnost, razvoj i zdrav okoliš - praksa odnošenja prema ljudskim pravima u stvarnome je životu drugačija. Poštivanje ljudskih prava važno je mjerilo demokracije te bi borba protiv njihova kršenja i zloupotrebe (osim kada se ona ograniče 
na strogo propisan način, u slučaju neke ugroze svih, poput ratne opasnosti) trebala biti sastavnim dijelom borbe za vladavinu prava i zaštitu svakog građanina u njegovim temeljnim pravima i slobodama, a što se jamči u ime općeprihvaćenih principa i prava koja pripadaju svim ljudima univerzalno.

Priče sa sadržajima o ljudskim pravima - od priča o borbama i patnjama koje su se odvijale kroz povijest borbe za ljudska prava i osude njihovih kršenja, do aktualnih i konkretnih životnih priča s takvim iskustvima - mogu nas potaknuti na društvenu promjenu i reagiranje na stanja ljudskih patnji jer se osjećamo odgovornima djelovati kao osviješteni građani. Pri tome ne treba gubiti povjerenje u funkcioniranje društva i institucija koje bi trebale štititi ljudska prava, nego treba dodatno razvijati mehanizme kritičnosti i nepristrane građanske kontrole pri primjeni zakona, s obzirom da smo sudionici društva za koje očekujemo da funkcionira temeljem humanosti i vladavine prava. Književnu imaginaciju Nussbaum u tome smislu vidi kao dio poticanja javne racionalnosti i odgovornosti svakog osviještenog građanina. Uživljavanje u situacije drugih doprinosi pravednosti i želji za utjecanjem na razrješavanje nepravdi.

»Čitanje romana neće nam reći sve o društvenoj pravednosti, ali može poslužiti kao most prema viziji pravednosti i ostvarenju te vizije u društvu.« (Nussbaum, 2005, 34)

Dublje sagledavanje konteksta i poruka priče, slojevito zahvaćanje motiva i razloga iz kojih ljudi djeluju kada se nalaze u situacijama u kojima se krše ljudska prava aktivira osjećaje vezane uz brigu za drugog, potiče spremnost na preuzimanje odgovornosti u vezi razotkrivanja teških nepravdi (razne vrste iskorištavanja, terorizam, siromaštvo, nezaposlenost, migracije, itd.) koje stvaraju traume, često puno gore u životu nego u pričama.

Odgovor na sve to trebao bi biti angažman oko rješavanja konkretnih problema, kao reakcija na iskustva povrede čovjeka i njegovih prava. Ili, kako kaže N. Govedić sumirajući apel mnogih koji se bave politikama brižnosti: »morat ćemo naučiti zahtijevati odgovornost za svako djelovanje koje ugrožava ljudska prava, ma gdje na svijetu « (Govedić, 2005, 31).

Upravo pomoću priča možemo potaknuti razvijanje moralne svijesti i osjetljivosti na pitanja ljudskih prava. Priče mogu navesti na promišljanja o položaju u kojemu se nalaze njihovi akteri s obzirom na 
doživljavanje patnje, nepravdi, zanemarivanja, raznih rizika po sebe i svoje bližnje, a imajući u vidu standarde koje bi trebalo osigurati u vezi poštivanja ljudskih prava. Cilj je demokratskog odgoja u tome smislu razvoj mišljenja, kognitivnih i afektivnih vještina koje na sudjelujući način osvještavaju potrebu svakog čovjeka na suočavanje s izazovima iz područja zaštite ljudskih prava u stvarnom životu.

\section{Neke smjernice u korištenju priča}

Priče koje se mogu odgojno koristiti vezano uz teme nepoštivanja i kršenja ljudskih prava prvenstveno su priče vezane uz prepoznavanje takvih pojava te one koje opisuju otpor nepravdama. Takav tip priča najviše može potaknuti suosjećajno i kritičko promišljanje te razumijevanje problema. Na različitim stupnjevima obrazovanja odabiru se odgovarajuće priče sa sadržajima vezanima uz neki oblik kršenja ljudskih prava, a može se ponuditi i mogućnost da se vlastito iskustvo u vezi s doživljenom nepravdom podijeli s drugima kako bi ga se suosjećajno i kritički sagledalo. Učenici se mogu podijeliti u manje grupe u kojima bi slobodno i neopterećeno te uz uzajamno povjerenje analizirali predočene teme iz različitih aspekata. Time se ujedno uvježbava kritičko mišljenje, uvažavanje drugačijih mišljenja te prepoznaje važnost podrške koju treba pružiti drugima u situacijama kada se krše neka od ljudskih prava. Bilo bi dobro da se, gdje je to moguće, kroz usporedbe s dokumentima kojima se jamče određena ljudska prava analiziraju raskoraci između proklamiranoga i onoga što se odvija u stvarnome životu.

Kada se radi o istinitim i proživljenim iskustvima, primjer može biti autobiografija Malale Yousafza, djevojčice koja se u turbulentnim političkim prilikama u svojoj zemlji našla u situaciji da se, zajedno s drugima, bori protiv kršenja prava na obrazovanje, posebno obrazovanje djevojčica. Obrazovanje je ogroman resurs i pravo koje može bitno pomoći u ostvarenju naših budućih interesa, naravno ako se to pravo ostvaruje. Ako neka prava u pojedinim društvima i nekim nametnutim okolnostima ne samo da nemaju moć nego članovi društva gaze principe pomoću kojih bi se ta moć ispravno primjenjivala te direktno krše prava ne prezajući od napada na ljude i njihove živote, onda možemo zamisliti čemu se sve treba izlagati da bi se branila vlastita prava. Malalina hrabrost i odlučnost u potraživanju prava za sebe i druge, uz ogromnu izloženost i preživljeni napad na vlastiti život, usmjerila je 
pažnju svijeta na dubinu tih problema i ukorijenjenost nepravdi na koje je čovječanstvo dužno reagirati. Potrebno je suzbijati razne fundamentalizme i ugrožavanja ljudi u življenju univerzalnih ljudskih prava jer su ona dio civilizacijskih dosega.

Nužno je pažljivo odmjeriti kada i kako djeci predočavati takve sadržaje. Budući da djeca od rane dobi imaju razvijen osjećaj za pravednost, on se može iskoristiti za rano započinjanje učenja u vezi ljudskih prava. Pritom je potrebno voditi računa kako o razvojnim mogućnostima djeteta tako i o njegovim mogućnostima uživljavanja u situacije i osjećaje. Neprimjerni sadržaji mogu narušiti njihovo povjerenje u svijet oko sebe i njihov osjećaj sigurnosti. Djeca druge ljude i njihove situacije doživljavaju kao pojedince, a teže im je razumjeti kontekste u kojima se nalaze, što ponekad kod njih izaziva veću zabrinutost za druge. Dječja prosudba priča o ljudima koji se bore za svoja prava treba biti dio njihova razumijevanja vrijednosti poštivanja i zaštite ljudskih prava, kao dio zalaganja za svijet u kojemu se ta prava dosljedno i pouzdano štite.

U tome smislu korisno je da se kroz nastavni proces učenici upoznaju sa sadržajem ljudskih prava te značenjem najvažnijih dokumenata iz toga područja. Upućuje ih se na sagledavanje pojedinih situacija u svjetlu standarda poštivanja ljudskih prava te potiče na osvještavanje očekivanja u vezi onoga što bi netko trebao omogućiti i zaštititi. Ujedno im se jača svijest o potrebi sprječavanja zloupotrebe ljudskih prava. Globalizirani svijet već sada svoju međuovisnost i umreženost sve više koristi za razotkrivanje takvih problema te za civilizirane oblike pritiska u smjeru njihova rješavanja, bez obzira gdje se događaju.

Također je važno da se kroz priče o doživljenim traumatičnim osobnim i kolektivnim iskustvima čovječanstvo u cjelini bori protiv zaborava i izvlači pouke u ime humanosti. Dnevnik Anne Frank (2000) primjer je istinite i snažne priče u koju je upisano proživljeno iskustvo zatvorenosti u svijet zbog događaja koje je pokrenulo bezumno zlo koje je ljudima negiralo pravo na ostvarenje, nadanja, opstanak, budućnost. Ne može nas ne dotaknuti izuzetnost pisanja djevojčice koja ne zna što je čeka, koja, bilježeći događaje u dnevnik, očekuje svoje sutra, da bi to sutra bilo prekinuto ljudskim zlom, jednako kao što ono i danas prekida brojne životne planove, uništava identitete, živote pojedinaca i narode. Do onoga koji čita, komentira, razmjenjuje svoje doživljaje i uočene pouke mora doprijeti svijest o ranama koje su ljudi i čovječanstvo proživjeli i koje se ne smiju ponavljati. 
»Kao pedagozi moramo se boriti protiv dehumanizacije i moramo se kao ljudska bića sjećati ljudi koji su bili dio života na svijetu i koji su nas napustili.« (Holokaust, 2006, 28)

Nažalost i danas, na drugačije načine, svjedočimo raznim oblicima nepoštivanja humanosti i kršenja ljudskih prava. Odgojem zrele javne svijesti treba se neumorno i odgovorno zalagati za poštivanje čovjeka i njegovih prava. Važno je također osvijestiti da i kroz obrazovni sustav - koji bi trebao biti potporom i modelom za humaniziranje ljudi i razvoj svih njihovih potencijala - djeca i mladi često doživljavaju razne nepravde, nerazumijevanje, zapuštanje, isključivanje temeljem predrasuda i diskriminiranja, čime se također u odgoju i kroz obrazovni sustav treba više i uspješnije baviti.

\section{Ukazivanje na negativne pojave nepoštivanja čovjeka i njegovih prava}

Prepoznavanje da pri kršenju ljudskih prava, nepoštivanju čovjeka i njegova dostojanstva ljudi doživljavaju poniženje i degradaciju, trebalo bi biti početnim korakom u razumijevanju i rješavanju tih problema. Poniženje često sadrži isključivanje i stvaranje osjećaja gubitka kontrole nad svojim životom i okolnostima koje ga uvjetuju, a da čovjek sam to nije prouzročio i izabrao. Isključivanje više nije samo fizičko isključivanje iz društva i utjecaja nego se ono vrši i preko manipuliranja informacijama, neuvažavanjem nečijih sposobnosti i perspektiva čime se pojedinca onemogućuje u razvoju, neuvažavanjem osobnosti, identiteta i perspektiva onoga koga se ponižava i isključuje. Takve situacije naginju i degradiranju, a ljudsko dostojanstvo ugroženo je kršenjem i negiranjem čovjekovih htjenja i postignuća, koja su povezana s identitetom i osjećajem osobne vrijednosti. Svaki čovjek koji se rukovodi savješću i poštivanjem zakona treba osuditi degradaciju drugoga kao nedopušteno ponašanje.

Iako ponižavanje i degradacija najčešće imaju za cilj napasti nečije samopoštovanje, taj cilj ne moraju uvijek postići. Jakost osobe, njen integritet i samopoštovanje te razumijevanje konteksta mogu biti branama pred pokušajima ponižavanja. Neke osobe, a posebno djeca i mladi ljudi, nisu dovoljno jaki da bi mogli bez poteškoća obraniti i sačuvati svoj identitet, vrijednost i samopoštovanje. Odgoj i društvo u cjelini stoga moraju dati podršku u zaštiti standarda poštivanja čovjeka i nje- 
govih prava, moralno i pomoću zakona. Učenje o pravima, humanosti i obvezama društva u osnaživanju vladavine prava štiti sve ljude jednako i dosljedno te doprinosi jačanju moralne obaveze svakog čovjeka. Nepoštivanje osobe i nepoštivanje ljudskih prava često su povezani te $u$ određenim okolnostima mogu imati nesagledive posljedice. Toga moramo biti svjesni i braniti humanost na svakom koraku i u svakom segmentu postojanja, ustrajno se znanjem, primjenom zakona i odgovornošću svih odupirati stvaranju odnosa snaga u kojima prava i vrijednosti gube bitke unutar nepravednih sklopova moći, često poduprtih raznim interesnim manipulacijama.

Poučan je također način na koji u novijim svjetskim okolnostima Stephan Hessel (1917-2013), francuski diplomat, pisac i borac za ljudska prava, odgovara Srećku Horvatu na pitanje zašto danas tolike vlade zaobilaze poštivanje ljudskih prava:

»Njima manipuliraju velike ekonomske i financijske sile, kojima se vlade ne mogu oduprijeti. One su izgubile moć da izgrade drugačiju ekonomiju, jer ekonomiju diktiraju moćne međunarodne financijske sile. I stoga, kada govore o ljudskim pravima, oni zapravo misle o vlastitim interesima, nafti i drugim elementima tržišta. To je razlog zašto mi, građani naših država, moramo biti vjerni pravima koja smo pokušali ostvariti i od naših vlada tražiti da se ta prava ostvaruju: pravo na krov nad glavom, pravo na obrazovanje, pravo na zdravstveno osiguranje... Ta se ključna prava danas zanemaruju i novac koji ostvaruju financijske grupe sada je važniji od naših života. To je razlog zašto trebamo biti indignirani, jer nitko više ne mari za naš dignitet.« (Horvat, 2011, 106)

Kršenja ljudskih prava i zloupotrebe funkcioniranja društva javljaju se u različitim oblicima. Jedan od njih je i korupcija koja obuhvaća djelovanja koja, suprotno javnom interesu, zloupotrebljavaju korištenje javnih ovlasti i moći, čime se potkopavaju moral i temelji vladavine prava, odnosno dopušta se da se prava krše. Oblici korupcije su podmićivanje, favoriziranje, nepotizam, sukob interesa, pristranost i slično. Šteta od tih djelovanja odražava se na pojedince i na društvo u cjelini, gubi se povjerenje u funkcioniranje sustava i u mogućnost utjecanja na devijantna i nezakonita ponašanja. Danas je problem korupcije prisutan u većini zemalja, posebno onima manje razvijenima i tranzicijskim zemljama gdje je slabija kontrola provođenja zakona te su štete za pojedince i države ogromne. Svijest o štetnosti korupcije potrebno je jačati i kroz obrazovanje.

Još je Aristotel spominjao korupciju u svome djelu Politika te inzistirao na poštivanju zakona i suzbijanju kvarenja, tj. korupcije. Aristotel 
govori o potrebi da se mlade odgaja u duhu državnoga poretka, da ga kao građani ne bi kasnije zloupotrebljavali. Također, ukazuje da

»I od tih nepravednina jedne nastaju zbog obijesti, druge zbog zlotvorstva. Uz to, takvi najčešće ili izbjegavaju službu ili gramze za službom, a obje su te [sklonosti] škodljive državama.« (Aristotel, 1992, 129)

Aristotel pridaje veliku ulogu odgoju građana u duhu poštivanja zakona i zaziranja od zloupotrebe općeg dobra. Država se ne bi smjela oglušivati na nepravde i zloupotrebe, jer o tome ovisi opstanak ili propadanje državnih poredaka (Aristotel, 1992). Kroz različite sustave, načine vladanja i povijesne okolnosti odražavao se drugačiji odnos prema pitanjima korupcije. Većina je ljudi u tim situacijama bila objektom i trpjela razne nepravde. Današnja svijest nas kao građane obvezuje na reagiranje te aktivno uključivanje $u$ omogućavanje ponašanja koja ne krše, nego upravo jačaju povjerenje u ljude i sustav.

Priče poput Mladi sinekurist Ivana Vidića, Da živim još jedan dan Jurice Pavičića, Svjedoka Ksenije Kušec ili Urednog rukopisa Darka Šeparovića (zbirka Ispod stola. Najljepše antikorupcijske priče) mogle bi se koristiti kao materijal za rasprave sa starijim uzrastima učenika o zloupotrebama, njihovim uzrocima i posljedicama te otporu prema takvim oblicima ponašanja u društvu. Kritički promišljajući i raspravljajući sadržaj pojedine priče, stavljajući se u situaciju drugih i odgovorno razmatrajući društveni okvir u kojemu se primjeri zloupotreba zbivaju, otvaramo pitanja o tome zašto se takve pojave uopće događaju, koja je pritom uloga pojedinca a koja društva, koliko su ljudi osviješteni, hrabri i slobodni izabrati svoja ponašanja, a koliko su uvjetovani okolinom i utjecajima sredine, u čemu zakazuje odgoj i obrazovanje te tko bi u tome trebao pokazati više angažmana i preuzeti više odgovornosti.

Na primjer, Svjedok opisuje situaciju u kojoj čovjek pod pritiskom korumpiranog sustava i pojedinaca odustaje od svjedočenja koje bi doprinijelo utvrđivanju istine o tome kako se dogodila prometna nesreća u kojoj je izgubljen život djeteta. Međutim, prevagnuli su razlozi po kojima je briga za vlastitu sigurnost i svakodnevnicu potisnula potrebu iskazivanja građanske dužnosti prema istini i suosjećanje za žrtvu. Život se nastavlja dalje, a da pravda nije postignuta. Možemo se upitati kako se osjećaju sudionici u događaju znajući da nisu postupili kako su trebali, zašto se ne aktivira temeljna ljudska savjest i potreba za pravdom, zašto se ne vide dalekosežnije posljedice nepoštivanja prava? Priča Uredan rukopis opisuje na koji način sudjelovanje u korupciji može prerasti u 
igru tuđim životima te sudionicima uništiti život kada ih se razotkrije ili kada sami osvijeste dubinu posljedica korupcije - od činjenja drugih žrtvom, sada postaju žrtvama vlastitih djela. Učenicima možemo postaviti i druga, općenitija pitanja: Koje su posljedice korupcije? Doprinosi li društvena atmosfera nepravdama i grubim kršenjima prava? Zašto ljudi prihvaćaju takve oblike ponašanja, je li u pitanju osobna pokvarenost ili prešutno odobravanje zloupotrebe javnog u korist privatnog, bezdušnost $u$ odnosu na stradanja i patnje drugih? Kako osujetiti i ne dopustiti takva ponašanja, kako raditi na vraćanju povjerenja u sustav tamo gdje je ono bitno narušeno? Kako odgajati da spriječimo buduće takve pojave?

\section{Zaključak}

Iz filozofije odgoja koja propituje mogućnosti i smisao čovjekova odgovornog odnosa prema postojanju, sebi i drugima očitujući odgojenost i humanost, te iz onog narativnog razumljenog u širem smislu kao sredstva pomoću kojega se pričanje priča može uključiti u odgoj o ljudskim pravima i njihovom kršenju, otvaraju se široke mogućnosti filozofskih promišljanja o čovjekovu odnosu prema osjetljivim aspektima ljudskog iskustva u vezi raznih oblika kršenja ljudskih prava. Kroz kritičko i suosjećajno promišljanje sadržaja priča o kršenjima ljudskih prava, odgaja se kod budućih odgovornih i osviještenih građana svijest o potrebi angažiranja oko rješavanja takvih problema. Zalaganje za standarde u poštivanju čovjeka i njegovih prava postavlja se kao imperativ za život u zajednici s drugima, a prepoznavanje i sprječavanje kršenja ljudskih prava kao moralna i društvena odgovornost. Sve to potkrepljuje potrebu da se angažiramo kroz filozofsku otvorenost za raspravu jer:

»Najgori je stav ravnodušnost, kazati 'ja tu ništa ne mogu, ne snalazim se'; takvim ponašanjem gubite jedan od bitnih sastojaka koji vas čini čovjekom." (Hessel, 2011, 19)

Svatko od nas bi trebao, kroz profesionalnu i osobnu usmjerenost, nastojati djelovati tako da svijet i njegovo funkcioniranje pomičemo naprijed u humanosti te doprinosimo razvoju demokratskog društva. To je potrebno i zato da se neke bolne priče čovječanstva ne bi ponavljale. Priče koje trebamo ispisivati neka se sastoje, uz pomoć suvremenih komunikacijskih i ostalih mogućnosti, »u društvenoj odgovornosti 
i pokušaju da se društvo, u vremenu kada društva nema - mijenja. Ne povlađivanje, nego promjena« (Horvat, 2011, 11).

Promjena i pozitivno zalaganje kroz koje će, odgovornošću svih nas, kršenja ljudskih prava biti što manje.

\section{Literatura}

Aristotel (1992), Politika, prijevod T. Ladan, Zagreb: Hrvatska sveučilišna naklada.

Čačinović, Nadežda (2012), Kultura i civilizacija. Što nas čini ljudima ili o procesu proizvodnje značenja i njegovim granicama, Zagreb: Školska knjiga.

Frank, Anne (2000), Dnevnik Anne Frank, Split: Marjan knjiga.

Govedić, Nataša (2005), Etičke bilježnice. O revoltu i brižnosti, Zagreb: Naklada Jesenski i Turk.

Grupa autora (2011), Ispod stola, Najljepše antikorupcijske priče, Zagreb: V.B.Z. d.o.o.

Hessel, Stẻphane (2011), Pobunite se!, Zagreb: V.B.Z. d.o.o.

Holokaust. Ljudska prava i obrazovanje (2006), Zagreb: Židovska općina Zagreb.

Horvat, Srećko (2011), Pažnja! Neprijatelj prisluškuje! Razgovori s vodećim intelektualcima današnjice, Zagreb: Naklada Ljevak d.o.o.

Matulović, Miomir (1996), Ljudska prava. Uvod u teoriju ljudskih prava, Zagreb: Hrvatsko filozofsko društvo.

MacIntyre, Alasdair C. (2002), Za vrlinom:studija o teoriji morala, Zagreb: KruZak.

Nussbaum, Marta C. (2003), Cultivating Humanity, A Classical Defense of Reform in Liberal Education, London: Harvard University Press.

Nussbaum, Martha C. (2005), Pjesnička pravda: književna imaginacija i javni život, Zagreb: Deltakont.

Sen, Amartya (2007), Identitet i nasilje, Zagreb: Masmedia.

Spajić-Vrkaš, Vedrana (ur.) (2001), Obrazovanje za ljudska prava i demokraciju: Zbirka međunarodnih i domaćih dokumenata, Zagreb: Hrvatsko povjerenstvo za UNESCO.

Yousafzai, Malala (2013), Ja sam Malala, s Cristinom Lamb, Zagreb: Profil. 


\section{PHILOSOPHY OF EDUCATION AND THE EDUCATIONAL ROLE OF STORYTELLING CONCERNING THE VIOLATION OF HUMAN RIGHTS}

\section{Milena Radovan Burja}

The text elaborates on the possibilities of philosophical reflection on the educational role of storytelling, especially regarding the issues of disrespect, misuse, and violation of human rights. Storytelling as an educational activity could be directed towards raising students' awareness regarding different phenomena that corrupt human rights and moral in society. Stories - which can serve as an important source for understanding the context surrounding the imagined or real-life situations of human rights violation - should be examined with a critical distance and compassion in order to develop the sense of personal and social responsibility regarding the respect of human rights.

Key words: philosophy of education, human rights, education, critical thinking, responsibility 